\title{
Chemical Components of the Rhizome Oil of Curcuma Heyneana Val.
}

\author{
Hasnah M. Sirat, \& Lee Lay Meng \\ Department of Chemistry, Faculty of Science, Universiti Teknologi Malaysia, 81310 Skudai, Johor, Malaysia. \\ *hasnah@ kimia.fs.utm.my (corresponding author) \\ Received on $14^{\text {th }}$ November 2008, accepted in revised form $18^{\text {th }}$ August 2009.
}

\begin{abstract}
The chemical composition of the essential oil of Curcuma heyneana isolated by hydrodistillation was analyzed by capillary GC and GC/MS. The main constituents found in the oil were sesquiterpenoids, curcumanolide (19.6\%), dehydrocurdione (17.2\%), isocurcumenol (16.5\%), curcumenol (13.7\%), curcumenone (6.4\%), and germacrone (5.0\%). A diterpenoid identified as labda-8(17), 12-diene-15, 16-dial (4.8\%) was also found as one of the components in the oil. These constituents were also isolated and identified from the chloroform extract of the dried rhizomes.
\end{abstract}

ABSTRAK Komposisi kimia minyak pati Curcuma heyneana yang diperoleh secara penyulingan hidro dianalisis dengan $\mathrm{KG}$ rerambut dan $\mathrm{KG} / \mathrm{SJ}$. Komponen utamanya terdiri daripada seskuiterpena, kurkumanolida (19.6\%), dehidrokurdion (17.2\%), isokurkumenol (13.7\%), kurkumenon (6.4\%), dan germakron (5.0\%). Sebatian diterpenoid, labda-8(17),12-diena-15,16-dial (4.8\%) juga dikenalpasti sebagai satu daripada komponen dalam minyak pati ini. Komponen kimia ini juga telah diasingkan dan dikenalpasti daripada ekstrak kloroform rizom kering.

(Keywords: Curcuma heyneana, essential oil composition, sesquiterpenoids, diterpene, cytotoxicity.)

\section{INTRODUCTION}

Curcuma heyneana Val. \& V. Zijp (Zingiberaceae) or locally known as temu giring is one of the medicinal plants indigenous to Indonesia. The rhizomes are aromatic, pale yellow, and do not contain curcumin, and are useful for the treatment of skin diseases. Isolation of the essential oil extracted from the dried rhizomes has been reported by Firman et al. [1]. The oil consists mainly sesquiterpenoids, identified as germacrone, dehydrocurdione, isocurcumenol, curcumenol, curcumanolide A and B, zerumbone and oxycurcumenol. However, they did not study chemical compositions of the essential oil in detail. More recently, analysis of the rhizomes oil of $C$. heyneana gave completely different constituents, mainly sesquiterpenes, i.e. $\beta$-pinene, $\gamma$-terpinene, guaiazulene, $\alpha$-copaene, $\delta$-elemene, 2 -undecanone, and carvone [2]. Our study showed a different result, therefore we reinvestigate the rhizomes oil again, and here we would like to report the chemical compositions of the fresh rhizomes and the isolationidentification of phytochemicals obtained from $C$. heyneana collected from Padang, Sumatera, Indonesia.

\section{EXPERIMENTAL}

\section{Plant material}

Fresh rhizomes of $C$. heyneana were collected from Bukit Tinggi, Padang, Sumatera, Indonesia. A voucher specimen had been deposited at the Herbarium of the Department of Botany, University of Andalas, Padang, Sumatera, Indonesia.

\section{Isolation Procedure}

Fresh rhizomes $(500 \mathrm{~g})$ were hydrodistilled in an allglass apparatus for $8 \mathrm{~h}$. Extraction of the distillate with diethyl ether, followed by drying over anhydrous magnesium sulphate and removal of the solvent yielded $0.43 \%(\mathrm{w} / \mathrm{w})$ of oil. The oil constituents were determined by GC and GC/MS.

GC

A Hewlett-Packard HP 5880A system equipped with an FID and an Ultra 1 gas chromatograph capillary column (cross-linked methyl silicone gum), (25m x $0.32 \mathrm{~mm} ; 0.20 \mu \mathrm{m}$ film thickness) was employed. Operating conditions: initial oven temperatural $50^{\circ} \mathrm{C}$ for $5 \mathrm{~min}, 50^{\circ}-300^{\circ} \mathrm{C}$ at $6^{\circ} \mathrm{C} / \mathrm{min}$ and then $300^{\circ} \mathrm{C}$ for $30 \mathrm{~min}$; injector temperature, $250^{\circ} \mathrm{C}$, carrier gas 1.0 $\mathrm{mL} / \mathrm{min} \mathrm{He}$, sample size $0.4 \mu \mathrm{L}$. The percentage composition of the oil was computed electronically from the GC peak areas without the use of an internal standard or detector response factors. 


\section{GC/MS}

A Hewlett-Packard 5989A GC/MS system equipped with Wiley Library software was used. Capillary GC conditions as above were employed. Significant operating parameters; ionization voltage, $70 \mathrm{eV}$; ion source temprature, $200^{\circ} \mathrm{C}$; scan mass range, 40 $350 \mu$.

\section{Component identification}

Sample components were identified by matching their mass spectra with those recorded in the MS Wiley Library and further supported by comparison of their GC retention times, TLC and MS with those of reference compounds when the latter were available.

\section{Isolation of Phytochemicals}

The essential oil $(0.75 \mathrm{~g})$ was purified by gravity column chromatography using silica gel $(70 \mathrm{~g})$ in a column (diameter $3 \mathrm{~cm}$ ) with a mixture of $\mathrm{PE}: \mathrm{Et}_{2} \mathrm{O}$ (99:1, 9:1 and 4:1) as eluents to give 207 fractions.

\section{Germacrone (1)}

Fractions (24-42) were combined and concentrated to give germacrone (1) $(21.6 \mathrm{mg}, 2.88 \%)$ as a colourless crystal, mp. $52-54^{\circ} \mathrm{C}$ (lit. [1] $55-56^{\circ} \mathrm{C}$, lit. [3] 53-54 ${ }^{\circ} \mathrm{C}$ and lit. [4] 53-55 $\left.{ }^{\circ} \mathrm{C}\right)$. IR $\left(\mathrm{CHCl}_{3}\right) v_{\max }$ $\mathrm{cm}^{-1}: 2923,1679,1439$ and $1386 ;{ }^{1} \mathrm{H} \mathrm{NMR}\left(\mathrm{CDCl}_{3}\right)$ : $\delta 1.40(3 \mathrm{H}, \mathrm{s}, \mathrm{H}-14), 1.59$ (3H, s, H-15), $1.69(3 \mathrm{H}, \mathrm{s}$, $\mathrm{H}-13), 1.74(3 \mathrm{H}, \mathrm{s}, \mathrm{H}-12), 2.0-2.40(4 \mathrm{H}, \mathrm{m}, \mathrm{H}-2$ and $\mathrm{H}-3), 2.80-3.00(3 \mathrm{H}, \mathrm{m}, \mathrm{H}-6$ and $\mathrm{H}-9 \mathrm{a}), 3.38(1 \mathrm{H}, \mathrm{d}$, $J 10.4 \mathrm{~Hz}, \mathrm{H}-9 \mathrm{~b}), 4.68(1 \mathrm{H}$, br.d, $J 10.4 \mathrm{~Hz}, \mathrm{H}-5)$ and $4.95(1 \mathrm{H}$, br.d, $J 11.6 \mathrm{~Hz}, \mathrm{H}-1) ;{ }^{13} \mathrm{C}$ NMR $\left(\mathrm{CDCl}_{3}\right): \delta$ 15.6 (C-14), 16.7 (C-15), 19.9 (C-12), 22.3 (C-13), 24.1 (C-2), 29.2 (C-6), 38.1 (C-3), 55.9 (C-9), 125.4 (C-5), 126.7 (C-4), 129.5 (C-7), 132.7 (C-1), 135.0 (C-10), 137.2 (C-11) and 207.9 (C-8); MS: $\mathrm{m} / z$ (\%) 218 (19) $\left[\mathrm{M}^{+}, \mathrm{C}_{15} \mathrm{H}_{22} \mathrm{O}\right], 136$ (81), 135 (73), 107 (100) and 67 (63).

\section{Curcumanolide A (2) and Curcumanolide B (3)}

Fractions (64-82) were combined and the solvent was evaporated in vacuo using rotary evaporator to yield a mixture of curcumanolide A (106) and curcumanolide B (107) $(76.6 \mathrm{mg}, 10.21 \%)$ as a yellow liquid. IR $v_{\max } \mathrm{cm}^{-1}: 2959,1744,1666,1449$, 1376 and $1269 ;{ }^{1} \mathrm{H}$ NMR $\left(\mathrm{CDCl}_{3}\right): \delta 0.84(3 \mathrm{H}, \mathrm{d}, J$ $\left.6.8 \mathrm{~Hz}, \mathrm{H}-14_{(2)}\right), 0.94\left(3 \mathrm{H}, \mathrm{d}, J 6.0 \mathrm{~Hz}, \mathrm{H}-14_{(3)}\right), 1.55$ $\left(3 \mathrm{H}, \mathrm{s}, \mathrm{H}-15_{(3)}\right), 1.70\left(3 \mathrm{H}, \mathrm{s}, \mathrm{H}-15_{(2)}\right), 1.81(6 \mathrm{H}, \mathrm{s}, \mathrm{H}-$ $\left.13_{(2),(3)}\right), 2.21\left(6 \mathrm{H}, \mathrm{t}, J 2.0 \mathrm{~Hz}, \mathrm{H}-12_{(2),(3)}\right), 2.43(3 \mathrm{H}$, $\mathrm{s}, \mathrm{H}-\mathrm{6}_{(2)}$ and $\left.\mathrm{H}-6 \mathrm{a}_{(3)}\right), 1.5-2.35\left(10 \mathrm{H}, \mathrm{m}, \mathrm{H}-2_{(2),(2)}, \mathrm{H}-\right.$ $3_{(2),(2)}$ dan $\left.\mathrm{H}-4_{(2),(3)}\right), 2.8-2.90\left(3 \mathrm{H}, \mathrm{m}, \mathrm{H}-1_{(2),(3)}\right.$ dan $\left.\mathrm{H}-6 \mathrm{~b}_{(3)}\right), 4.73\left(2 \mathrm{H}, \mathrm{s}, \mathrm{H}-9 \mathrm{a}_{(2),(3)}\right), 4.85\left(1 \mathrm{H}, \mathrm{s}, \mathrm{H}-9 \mathrm{~b}_{(3)}\right)$ and $4.92\left(1 \mathrm{H}, \mathrm{s}, \mathrm{H}-9 \mathrm{~b}_{(2)}\right) ;{ }^{13} \mathrm{C}$ NMR $\left(\mathrm{CDCl}_{3}\right): \delta 13.0$ $\left(\mathrm{C}-14_{(3)}\right), 13.1$ (C-14 $\left._{(2)}\right), 19.8\left(\mathrm{C}-15_{(3)}\right), 19.9$ (C-15 $\left.{ }_{(2)}\right), 21.9\left(\mathrm{C}-13_{(3)}\right), 23.1\left(\mathrm{C}-3_{(2)}\right), 23.9\left(\mathrm{C}-13_{(3)}\right), 24.4$ (C-12 (2), (3)), 26.3 (C-2 (2) $), 27.4\left(\mathrm{C}-6_{(3)}\right), 27.5$ (C-6 (2)), 30.8 (C-3 (3) $), 33.8$ (C-2 (3) $), 42.7$ (C-4 (2) $), 45.2$ $\left(\mathrm{C}-4{ }_{(3)}\right), 52.1\left(\mathrm{C}-1_{(2)}\right), 56.0\left(\mathrm{C}-1_{(3)}\right), 89.6\left(\mathrm{C}-5_{(2)}\right)$, $91.6\left(\mathrm{C}-5_{(3)}\right), 112.7\left(\mathrm{C}-9_{(2)}\right), 114.0\left(\mathrm{C}-9_{(3)}\right), 120.7(\mathrm{C}-$ $\left.7_{(2),(3)}\right), 143.7\left(\mathrm{C}-11_{(2)}\right), 145.3\left(\mathrm{C}-11_{(3)}\right), 149.3(\mathrm{C}-10$ (2), (3) ) dan $169.8\left(\mathrm{C}-8_{(2),(3)}\right)$; MS: $m / z$ (\%) 234 (33) $\left[\mathrm{M}^{+}, \mathrm{C}_{15} \mathrm{H}_{22} \mathrm{O}_{2}\right], 178$ (50), 165 (80), 164 (100) dan $152(85)$.

\section{Isocurcumenol (4)}

Fractions (105-118) were combined and concentrated, followed by recrystallization using petroleum ether to give isocurcumenol (4) $(54.8 \mathrm{mg}$, $7.31 \%$ ) as colourless crystals, mp. $145-147^{\circ} \mathrm{C}$ (lit. [1] $\left.144-146^{\circ} \mathrm{C}\right)$. IR $\left(\mathrm{CHCl}_{3}\right) v_{\max } \mathrm{cm}^{-1}: 3405,2928$, 1644, 1453, 1373 and 1216; ${ }^{1} \mathrm{H}$ NMR $\left(\mathrm{CDCl}_{3}\right): \delta$ $0.98(3 \mathrm{H}, \mathrm{d}, J 6.4 \mathrm{~Hz}, \mathrm{H}-14), 1.54$ (3H, s, H-13), 1.77 (3H, s, H-12), 1.6-2.00 (6H, m, H-2, H-3 and H-6), $2.19(1 \mathrm{H}, \mathrm{t}, J 14.0 \mathrm{~Hz}, \mathrm{H}-4), 2.4-2.60(2 \mathrm{H}, \mathrm{m}, \mathrm{H}-9)$, $2.65(1 \mathrm{H}, \mathrm{d}, J 14.0 \mathrm{~Hz}, \mathrm{H}-1), 2.78(1 \mathrm{H}, \mathrm{s}, \mathrm{OH}), 4.71$ $(1 \mathrm{H}, \mathrm{t}, J 2.0 \mathrm{~Hz}, \mathrm{H}-15 \mathrm{a})$ and $4.75(1 \mathrm{H}, \mathrm{t}, J 2.0 \mathrm{~Hz}, \mathrm{H}-$ $15 \mathrm{~b}) ;{ }^{13} \mathrm{C} \mathrm{NMR}\left(\mathrm{CDCl}_{3}\right): \delta 12.4(\mathrm{C}-14), 18.9(\mathrm{C}-13)$, 22.5 (C-12), 28.3 (C-2), 30.8 (C-3), 36.2 (C-9), 38.9 (C-6), 41.6 (C-4), 52.8 (C-1), 87.1 (C-5), 104.0 (C-8), 112.2 (C-15), 126.9 (C-11), 133.9 (C-7) and 145.1 (C-10); MS: $m / z$ (\%) 234 (3) $\left[\mathrm{M}^{+}, \mathrm{C}_{15} \mathrm{H}_{22} \mathrm{O}_{2}\right], 191$ (35), 121 (48), 105 (100), 67 (55) and 41 (87).

\section{Curcumenol (5)}

Fractions (127-159) were combined, followed by washing with petroleum ether repeatedly to give curcumenol (5) (45.6 mg, $6.08 \%)$ as colourless needles, mp $113-115^{\circ} \mathrm{C}$ (lit. [1] $114-116^{\circ} \mathrm{C}$ ). IR $\left(\mathrm{CHCl}_{3}\right) v_{\max } \mathrm{cm}^{-1}: 3378,2957,2873$ and $1653 ;{ }^{1} \mathrm{H}$ NMR $\left(\mathrm{CDCl}_{3}\right): \delta 0.98(3 \mathrm{H}, \mathrm{d}, J 6.4 \mathrm{~Hz}, \mathrm{H}-14), 1.55$ (3H, s, H-15), 1.61 (3H, s, H-13), 1.77 (3H, s, H-12), 1.8-2.00 (6H, m, H-2, H-3 and H-6), $2.07(1 \mathrm{H}, \mathrm{d}, J$ $15.6 \mathrm{~Hz}, \mathrm{H}-1), 2.61(1 \mathrm{H}, \mathrm{d}, J 15.6 \mathrm{~Hz}, \mathrm{H}-4), 3.05$ $(1 \mathrm{H}, \mathrm{s}, \mathrm{OH})$ and $5.71(1 \mathrm{H}, \mathrm{s}, \mathrm{H}-9) ;{ }^{13} \mathrm{C}$ NMR $\left(\mathrm{CDCl}_{3}\right): \delta 11.8(\mathrm{C}-14), 20.9$ (C-15), 18.9 (C-13), 22.3 (C-12), 27.5 (C-2), 31.2 (C-3), 37.1 (C-6), 40.3 (C-4), 51.2 (C-1), 85.7 (C-5), 101.5 (C-8), 122.1 (C11), 125.8 (C-9), 137.2 (C-10) and 139.0 (C-7); MS: $\mathrm{m} / z(\%) 234$ (15) $\left[\mathrm{M}^{+}, \mathrm{C}_{15} \mathrm{H}_{22} \mathrm{O}_{2}\right], 189$ (26), 147 (30), 133 (38), 105 (100) and 91 (38).

\section{Curcumenone (6)}

Fractions (182-201) were combined and the solvent was evaporated to yield curcumenone (6) $(23.6 \mathrm{mg}$, $3.15 \%$ ) as a viscous oil [5]. IR $v_{\max } \mathrm{cm}^{-1}: 2926,1716$, 1678, 1600, 1439 and $1369 ;{ }^{1} \mathrm{H}$ NMR $\left(\mathrm{CDCl}_{3}\right): \delta$ $0.41(1 \mathrm{H}, \mathrm{dt}, J 4.4$ and $7.2 \mathrm{~Hz}, \mathrm{H}-1), 0.64(1 \mathrm{H}, \mathrm{q}, J$ $4.4 \mathrm{~Hz}, \mathrm{H}-5), 1.09$ (3H, s, H-15), 1.57 (2H, q, J 7.2 Hz, H-2), 1.76 (3H, s, H-13), 2.06 (3H, s, H-12), 2.10 
(3H, s, H-14), 2.44 (2H, t, J $7.2 \mathrm{~Hz}, \mathrm{H}-3), 2.49$ (1H, s, H-9a), 2.51 (1H, s, H-9b) and 2.78 (2H, br.s, H-6); ${ }^{13} \mathrm{C} \mathrm{NMR}\left(\mathrm{CDCl}_{3}\right): \delta 19.0(\mathrm{C}-15), 20.1(\mathrm{C}-10), 23.3$ (C-14), 23.4 (C-12), 23.4 (C-13), 24.1 (C-5), 24.2 (C2), 28.0 (C-6), 30.0 (C-1), 43.9 (C-3), 48.9 (C-9), 128.0 (C-7), 147.3 (C-11), 201.6 (C-8) and 208.7 (C4); MS: $m / z$ (\%) 234 (14) $\left[\mathrm{M}^{+}, \mathrm{C}_{15} \mathrm{H}_{22} \mathrm{O}_{2}\right], 176$ (98), 161 (58), 133 (40), 107 (44), 91 (45) and 68 (100).

\section{Soxhlet Extraction of $\boldsymbol{C}$. Heyneana}

The dried rhizomes (59.4 g) was extracted using chloroform in a Soxhlet apparatus for $20 \mathrm{hr}$. Evaporation of the chloroform gave the crude extract (14.11 g, 23.75\%) as brown oil.

\section{Isolation and Identification of Constituents from the Soxhlet Extraction}

The crude extract $(8 \mathrm{~g})$ was fractionated using vacuum liquid chromatography with petroleum ether and ether as eluents produced 25 fractions. The fractions were then combined based on the TLC pattern to 3 fractions, fraction $1(0.75 \mathrm{~g})$, fraction 2 $(4.18 \mathrm{~g})$ and fraction $3(2.09 \mathrm{~g})$. Fraction 1 was purified using column chromatography to give germacrone (1) $(0.23 \mathrm{~g}, 2.88 \%)$ as colourless needles, mp. 52-54 ${ }^{\circ} \mathrm{C}$ (lit. [1] $55-56^{\circ} \mathrm{C}$, lit. [3] 53-54 ${ }^{\circ} \mathrm{C}$ and lit. [4] $53-55^{\circ} \mathrm{C}$ ); Fraction 2 was purified by column chromatography to give 172 fractions. Fractions were combined based on the TLC profile to yield a diterpene, labd-8(17), 12-dien-15, 16-dial (7) (76.5 $\mathrm{mg}, 0.96 \%)$ as yellowish oil [6]; dehydrocurdione (8) $(0.45 \mathrm{~g})$ as a colourless oil [7]; isocurcumenol (4) $(0.37 \mathrm{~g}, 4.63 \%)$ as colourless crystals, mp. 145$147^{\circ} \mathrm{C}$ (lit. [1] $\left.144-146^{\circ} \mathrm{C}\right)$; and curcumenol (5) (0.35 $\mathrm{g}, 4.38 \%$ ) as colourless crystals, mp. $113-115^{\circ} \mathrm{C}$ (lit. [1] $\left.114-116^{\circ} \mathrm{C}\right)$. Fraction $3(2.09 \mathrm{~g})$ was chromatographed to give curcumenone (6) $(0.11 \mathrm{~g}$, $1.38 \%$ ) as a yellow oil.

Labda-8(17), 12-dien-15, 16-dial (7)

IR $v_{\max } \mathrm{cm}^{-1}: 2930,2844,2717,1727,1685,1642$ and $889 ;{ }^{1} \mathrm{H}$ NMR $\left(\mathrm{CDCl}_{3}\right): \delta 0.70(3 \mathrm{H}, \mathrm{s}, \mathrm{H}-18)$, 0.79 (3H, s, H-19), 0.86 (3H, s, H-20), 1.0-2.10 (12H, m, H-1, H-2, H-3, H-5, H-6, H-7 and H-9), 2.3-2.50 (2H, m, H-11), 3.38 (1H, d, J $16.8 \mathrm{~Hz}, \mathrm{H}-14 \mathrm{a}), 3.47$ (1H, d, J 16.8 Hz, H-14b), 4.34 (1H, s, H-17a), 4.83 (1H, s, H-17b), 6.74 (1H, t, J $6.6 \mathrm{~Hz}, \mathrm{H}-12), 9.38$ $(1 \mathrm{H}, \mathrm{s}, \mathrm{H}-16)$ and $9.61(1 \mathrm{H}, \mathrm{s}, \mathrm{H}-15) ;{ }^{13} \mathrm{C} \mathrm{NMR}$ $\left(\mathrm{CDCl}_{3}\right): \delta 14.3(\mathrm{C}-20), 19.2(\mathrm{C}-2), 21.7$ (C-19), 24.1 (C-6), 24.6 (C-11), 33.5 (C-4), 33.5 (C-18), 37.8 (C14), 39.2 (C-1), 39.3 (C-7), 39.5 (C-10), 41.9 (C-3), 55.3 (C-5), 56.4 (C-9), 107.8 (C-17), 134.8 (C-13), 147.9 (C-8), 160.0 (C-12), $193.6(\mathrm{C}-16)$ and 197.1(C15); MS: $m / z(\%) 302(9)\left[\mathrm{M}^{+}, \mathrm{C}_{20} \mathrm{H}_{30} \mathrm{O}_{2}\right], 137$ (100), 123 (50), 95 (84) and 81 (94).
Dehydrocurdione (8)
$\left.{ }^{1} \mathrm{H} \mathrm{NMR} \mathrm{CDCl}_{3}\right): \delta 1.00(3 \mathrm{H}, \mathrm{d}, J 7.2 \mathrm{~Hz}, \mathrm{H}-14)$, $1.63(3 \mathrm{H}, \mathrm{s}, \mathrm{H}-15), 1.73$ (3H, s, H-13), 1.76 (3H, s, H-12), 1.0-2.10 (12H, m, H-1, H-2, H-3, H-5, H-6, $\mathrm{H}-7$ and $\mathrm{H}-9), 2.0-2.20$ (4H, m, H-2 and H-3), 2.3$2.50(3 \mathrm{H}, \mathrm{m}, \mathrm{H}-4), 3.0-3.15(4 \mathrm{H}, \mathrm{m}, \mathrm{H}-6$ and $\mathrm{H}-9)$, and5.13 (1H, br.s, H-1). Germacrone (1), isocurcumenol (4), curcumenol (5), curcumenone (6), and dehydrocurdione (8) isolated from the crude extract were identical to those obtained from the essential oil of the fresh rhizomes.

\section{Toxicity screening}

Bioassay screening of the rhizome oil against brine shrimps, Artemia salina was carried out using standard methods [10-11].

\section{Antimicrobial screening}

Screening on the rhizome oil and isolated compounds was carried out using disc diffusion assay [12-13] against three gram positive (Staphylococcus aureus, Bacillus subtilis, B. cereus, and five gram negative bacteria (Escherichia coli, Pseudomonas aeruginosa, Serratia marcescens, Salmonella typhii and Streptococcus faecalis) as well as four fungi with streptomycin sulfate and nystatin hydrate as positive controls respectively.

\section{RESULTS AND DISCUSSIONS}

The rhizomes of $C$. heyneana yielded $\sim 0.43 \%$ oil. Twenty four compounds representing more than $95 \%$ of the oil were identified. They are listed in Table I. Among these compounds were: 14 sesquiterpenes $(87.3 \%)$, one diterpene $(4.8 \%)$, and 8 monoterpenes (3.0\%). The major sesquiterpene were curcumanolides A and B (19.6\%), dehydrocurdione $(17.1 \%)$ and isocurcumenol (16.5\%). The rhizome oil of $C$. heyneana was found to be deficient in monoterpenoids. Most of the compounds found in the rhizomes oil reported earlier [2] contained different constituents; the only similar component present was 2 -undecanone with only $0.3 \%$. The essential oil reported earlier did not contain high amounts of sesquiterpenoids and also did not contain any diterpenoid constituent. In this study, only eight compounds of monoterpenes were detected in the oil, with linalool $(1.2 \%)$ as the major monoterpenoid. The differences between the results of the present analysis and the published data suggest that there may be two chemotypes of $C$. heyneana, but without further study this is merely a point of interest. 
Table 1. Chemical Composition of the rhizome oil of Curcuma heyneana

\begin{tabular}{|c|c|c|}
\hline Constituent & Area \% & Method of identification \\
\hline 1,8-Cineole & 0.2 & GC/MS \\
\hline Linalool & 1.2 & GC/MS \\
\hline Camphene hydrate & 0.1 & GC/MS \\
\hline Endoborneol & 0.3 & GC/MS \\
\hline Borneol & 0.3 & GC/MS \\
\hline$p$-Cymene-8-ol & 0.1 & GC/MS \\
\hline$\alpha$-Terpineol & 0.3 & GC/MS \\
\hline 2-Undecanone & 0.3 & GC/MS \\
\hline Isocaryophyllene & 0.6 & GC/MS \\
\hline$\gamma$-Elemene & 0.1 & GC/MS \\
\hline$\beta$-Caryophyllene & 0.2 & GC/MS \\
\hline$\alpha$-Humulene & 0.4 & GC/MS \\
\hline ar-Curcumene & 0.5 & $\mathrm{GC} / \mathrm{MS} / \mathrm{CoC}$ \\
\hline Furanodiene & 0.3 & GC/MS \\
\hline Curzerenone & 1.7 & GC/MS \\
\hline Caryophyllene oxide & 5.1 & GC/MS \\
\hline Isocurcumenol & 16.5 & $\mathrm{GC} / \mathrm{MS} / \mathrm{CoC}$ \\
\hline Germacrone & 5.0 & $\mathrm{GC} / \mathrm{MS} / \mathrm{CoC}$ \\
\hline Curcumenol & 13.7 & $\mathrm{GC} / \mathrm{MS} / \mathrm{CoC}$ \\
\hline Dehydrocurdione & 17.2 & $\mathrm{GC} / \mathrm{MS} / \mathrm{CoC}$ \\
\hline Curcumanolide & 19.6 & $\mathrm{GC} / \mathrm{MS} / \mathrm{CoC}$ \\
\hline Curcumenone & 6.4 & $\mathrm{GC} / \mathrm{MS} / \mathrm{CoC}$ \\
\hline Labda-8(17), 12-diene-15, 16-dial & 4.8 & $\mathrm{GC} / \mathrm{MS} / \mathrm{CoC}$ \\
\hline Total & $95 \%$ & \\
\hline
\end{tabular}

The major constituents in the rhizomes oil, germacrone (1), (curcumanolide A (2) \& B (3), isocurcumenol (4), curcumenol (5), curcumenone (6), labda-8(17), 12-diene-15,16-dial (7), and dehydrocurdione (8) as shown in Figure 1, have been isolated via gravity column chromatography on silica gel, and they were structurally elucidated spectroscopically by IR, ${ }^{1} \mathrm{H} \&{ }^{13} \mathrm{C}$ NMR and MS a These data were consistent with those reported earlier in the literatures [1, 3-9].

Preliminary screening on the toxicity of the oil of $C$. heyneana against brine shrimps, (Artemia salina)
[10-11], showed that the oil was quite toxic with $\mathrm{ED}_{50} 46.61 \mathrm{ppm}$. Antibacterial screening revealed that the oil only gave moderate activity against gram negative bacteria, Pseudomonas aeruginosa. The result also showed that a sesquiterpene, curcumenone (6) was active against $S$. aureus, B. subtilis, $P$. aeruginosa, B. cereus and $S$. faecalis, whereas a diterpene, labda-8(17),12-dien-15,16-dial (7) was active against $S$. aureus, B. subtilis, $P$. aeruginosa, and $S$. typhii, with the MIC value of $0.05-0.025$. Labda 8(17),12-dien-15,16-dial (7) was the only phytochemical found to be active against fungal 
screening, Cladosporium cladosporoides and Trichoderma $s p$. with the MIC value of 0.0125 $\mu \mathrm{g} / \mathrm{mL}$. This was consistent with literatures that this labdane diterpene isolated from turmeric leaves [14], and Alpinia galanga seeds [15] was found to show antifungal activity against Candida.<smiles>CC1=CCCC(C)=C(C)CCC1=C(C)C</smiles>

1

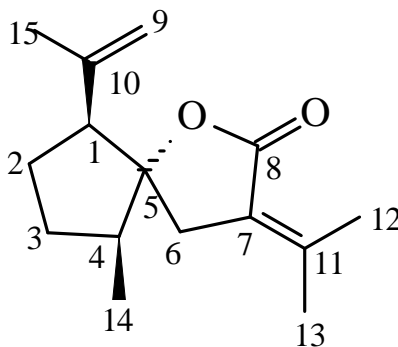

2



3

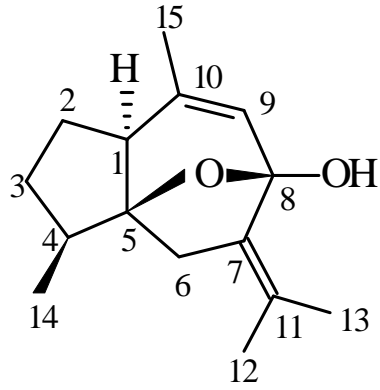

4

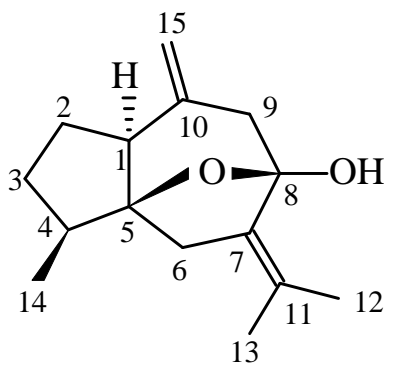

5



13

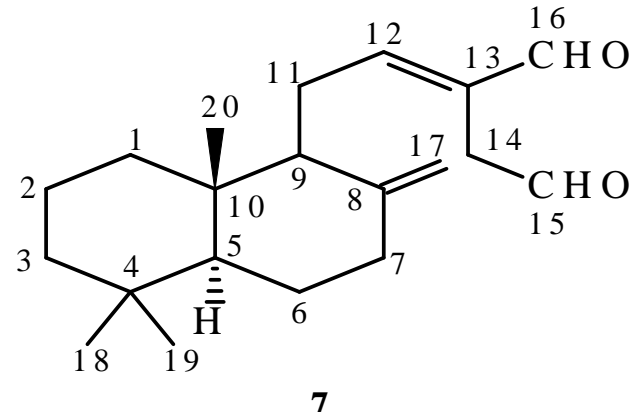

7<smiles>CC1CCC(C)C(=O)Cc2occ(I)c2C1</smiles>

8

Figure 1. Chemical components isolated from Curcuma heyneana

\section{CONCLUSIONS}

The rhizome oil of Curcuma heyneana was found to be rich in sesquiterpenes $(87.3 \%)$ with curcumanolide and dehydrocurdione as the major constituents $(19.6 \%)$ and $(17.2 \%)$ respectively. The rhizome oil of $C$. heyneana was also found to be quite toxic against A. salina with $\mathrm{ED}_{50} 46.61 \mathrm{ppm}$. Isolation and purification of the rhizomes oil yielded pure dehydrocurdione, curcumenol, isocurcumenol, curcumenone, germacrone and labda-8(17),12-diene15,16-dial, as well as curcumanolides $\mathrm{A}$ and $\mathrm{B}$. Zerumbone was not detected in this oil, as it had been reported in the previous literature [1], and this was probably due to the presence of zerumbone in a very minute quantity. Diterpene labda-8(17)12-dien-15, 16-dial (7) was reported for the first time in Curcuma heyneana. Curcumenone (6), and labda-8(17)12dien-15, 16-dial (7) were two pure components that showed moderate antibacterial activity, whereas 
labda-8(17)12-dien-15, 16-dial (7) was the only constituent that showed antifungal activity.

\section{ACKNOWLEDGEMENTS}

The authors wish to thank Mr. Abd. Kadir A. Rahman and Mr. Ayob Jabal for the help of GC and GC/MS, respectively. We also would like to thank Mr. Rusdji of University Andalas, Padang, Sumatera for sample identification, FELDA for financial support and Malaysian Government for scholarship to Lee Lay Meng.

\section{REFERENCES}

1. Firman, K. Kinoshita, T. Itai, A. and Sankawa, U. (1988). Terpenoids from Curcuma heyneana. Phytochemistry, 27, 3887 - 3891.

2. Amini, M. S. Miles, H. and Heden, P. (1996). GC-MS analysis on volatile oil of rhizomes of Curcuma heyneana Val. \& Van Zyp. Maj. Farm. Indonesia, 7, 78. Chem. Abstr. 128: 79788.

3. Kuroyanagi, M., Ueno, A., Ujiie, K. and Sato, S. (1987). Structures of Sesquiterpenes from Curcuma aromatica Salisb. Chem. Pharm. Bull. 35. 53 - 59.

4. Yamazaki, M., Maebayashi, Y., Iwase, N. and Kaneko, T. (1988). "Studies on Pharmacologically Active Principles from Indonesian Crude Drugs II. Hypothermic Principle from Curcuma xanthorrhiza Roxb." Chem. Pharm. Bull. 36. 2075 - 2078.

5. Shiobara, Y., Asakawa, Y., Kodama, M., Yasuda, K. and Takemoto, T. (1985). Curcumenone, Curcumanolide A and Curcumanolide B, Three Sesquiterpenoids from Curcuma zedoaria. Phytochemistry. 24. 2629 2633.

6. Sirat, H. M. Masri, D. and Rahman, A. A. (1994). Distribution of labdane diterpenes from Zingiberaceae of Malaysia, Phytochemistry, 36, $699-701$.

7. Hikino, H., Konno, C. and Takemoto, T. (1972). "Structure of Dehydrocurdione, a Sesquiterpenoid of Curcuma zedoaria." Chem. Pharm. Bull. 20. 987 - 989.

8. Sirat, H. M. Jamil, S. and Rahman, A. A. (1998). Sesquiterpenes from Curcuma aeruginosa, Planta Med., 64, 584 - 585.

9. Sirat, H. M. Jamil, S. and Hussain, J. (1998). The chemical compositions of the rhizomes oil of Curcuma aeruginosa, J. Essent. Oil Res., 10, 453 -.458 .
10. Meyer, B. N. Ferrigni, N. R. Putnam, J. E. Jacobsen, L. B. Nichols D. E. and McLaughlin, J. L. (1982). A convenient general bioassay for active plant constituents. Planta Med., 45, 31 34.

11. Lincoln, R. A. Strupinski, K. and. Walker, J. M. (1996). The use of Artemia nauplii (Brine shrimps larvae) to detect toxic compounds from microalgal cultures. Int. J. Pharmacog., 34, 384 389.

12. Atlas, R. M. (1997). Principles of Microbiology, $2^{\text {nd }}$ edition. Wm. C. Brown Publishers, USA, 472 $-486$.

13. Benson, H. J. (1994). Antimicrobic sensitivity testing: the Kirby-bauer Method" $6^{\text {th }}$ edition, Wm. C. Brown Publishers, USA, 137 - 139.

14. Roth, G. N., Chandra, A., Muraleedharan, G. (1998). Novel bioactivities of Curcuma longa constituents. J. Nat. Prod. 61, 542 - 545.

15. Morita, H., and Itokawa, H. (1988). Cytotoxic and antifungal diterpenes from the seeds of Alpinia galanga. Planta Med., 54, 117 - 120. 